\title{
QUALITY OF LIFE SOCIAL REPRESENTATIONS OF PEOPLE LIVING WITH HIV/AIDS
}

\author{
Juliana Pereira Domingues ${ }^{1}$, Denize Cristina de Oliveira², Sergio Correa Marques ${ }^{3}$
}

${ }^{1}$ M.Sc. in Nursing by the Postgraduate Program in Nursing at the State University of Rio de Janeiro. Professor at Gama \& Souza College. Rio de Janeiro, Rio de Janeiro, Brazil. E-mail: pdominguesjuliana@gmail.com

${ }^{2}$ Ph.D. in Public Health. Professor of the Department of Nursing Fundamentals and at the Postgraduate Program in Nursing of the Faculty of Nursing and the Program of Social Psychology of the Psychology Institute of UERJ. Rio de Janeiro, Rio de Janeiro, Brazil. E-mail: dcouerj@gmail.com

${ }^{3}$ Ph.D. in Nursing. Professor of the Department of Nursing Fundamentals and the Postgraduate Program in Nursing of the Faculty of Nursing of UERJ. Rio de Janeiro, Rio de Janeiro, Brazil. E-mail: sergiocmarques@uol.com.br.

\begin{abstract}
Objective: to analyze the social representations of the quality of life of people living with HIV/AIDS.

Method: a descriptive, exploratory study with a qualitative approach, based on the Theory of Social Representations, using the structural approach. It was carried out in three Specialized Care Services for HIV/AIDS, with 180 people living with HIV/AIDS in therapeutic followup in these services. In the data collection, questionnaires with socioeconomic variables and the technique of Word Free Evocations were applied to the term inducer "quality of life", in order to obtain the representation contents. The analysis of the data from the evocation was performed through the technique of the four-house table, being instrumentalized by the software called Ensemble de Programmes Permettant L'analysedes Evocations, version 2005.
\end{abstract}

Results: in the analysis of the representation structure of the "quality of life", the positive elements identified in the possible central nucleus were good food, health care and health, which suggest that the quality of life of the participants is associated with an adequate diet, which is inserted in the context of health care, evidencing the group's concern with their own health.

Conclusion: health is a priceless asset for the group studied. The social representations of quality of life are based on the adoption of health care related to self-care and, in particular, to health promotion actions.

DESCRIPTORS: Quality of life. HIV. Aids. Health promotion. Health care.

\section{REPRESENTAÇÕES SOCIAIS DA QUALIDADE DE VIDA DE PESSOAS QUE VIVEM COM HIV/AIDS}

\section{RESUMO}

Objetivo: analisar as representações sociais da qualidade de vida de pessoas que vivem com HIV/aids.

Método: estudo descritivo, exploratório, com abordagem qualitativa, fundamentado na Teoria das Representações Sociais, utilizando a abordagem estrutural. Foi realizado em três Serviços de Assistência Especializada em HIV/aids, com 180 pessoas que vivem com HIV/ aids em acompanhamento terapêutico nestes serviços. Na coleta de dados, aplicaram-se questionários com variáveis socioeconômicas e a técnica de Evocações Livres de Palavras ao termo indutor "qualidade de vida", para a obtenção dos conteúdos da representação. A análise dos dados provenientes da evocação foi realizada através da técnica do quadro de quatro casas, sendo instrumentalizada pelo software denominado Ensemble de Programmes Permettant L'analyse des Evocations, versão 2005.

Resultados: na análise da estrutura da representação da "qualidade de vida", identificaram-se, no possível núcleo central, os elementos positivos boa, boa-alimentação, cuidados-saúde e saúde, que sugerem que a qualidade de vida dos participantes está associada a uma alimentação adequada, a qual está inserida no contexto dos cuidados de saúde, evidenciando a preocupação do grupo com a própria saúde. Conclusão: a saúde é um bem inestimável para o grupo estudado. As representações sociais da qualidade de vida estão pautadas na adoção de cuidados de saúde relacionados com o cuidado de si e, em especial, com as ações de promoção da saúde.

DESCRITORES: Qualidade de vida. HIV. Aids. Promoção da saúde. Atenção à saúde. 


\title{
REPRESENTACIONES SOCIALES DE LA CALIDAD DE VIDA DE PERSONAS QUE VIVEN CON VIH/SIDA
}

\author{
RESUMEN \\ Objetivo: analizar las representaciones sociales de la calidad de vida de las personas que viven con el VIH/SIDA.
}

Método: estudio descriptivo, exploratorio, con abordaje cualitativo, fundamentado en la Teoría de las Representaciones Sociales, utilizando el abordaje estructural. Se realizó en tres Servicios de Asistencia Especializada en VIH/sida, con 180 personas que viven con VIH/sida en seguimiento terapéutico en estos servicios. En la recolección de datos, se aplicaron cuestionarios con variables socioeconómicas y la técnica de Evocaciones Libres de Palabras al término inductor "calidad de vida", para la obtención de los contenidos de la representación. El análisis de los datos provenientes de la evocación fue realizado a través de la técnica del cuadro de cuatro casas, siendo instrumentalizada por el software denominado Ensemble de Programmes Permettant L'analyse des Evocations, versión 2005.

Resultados: en el análisis de la estructura de la representación de la calidad de vida, se identificaron, en el posible núcleo central, los elementos positivos buena, buena alimentación, atención sanitaria y salud, que sugieren que la calidad de vida de los participantes está asociada a una alimentación adecuada, la cual está inserta en el contexto de la atención de salud, evidenciando la preocupación del grupo con la propia salud.

Conclusión: la salud es un bien inestimable para el grupo estudiado. Las representaciones sociales de la calidad de vida están pautadas en la adopción de cuidados de salud relacionados con el cuidado de sí y, en especial, con las acciones de promoción de la salud.

DESCRIPTORES: Calidad de vida. VIH. SIDA. Promoción de la salud. Atención a la salud.

\section{INTRODUCTION}

The infection caused by the Human Immunodeficiency Virus (HIV) affects approximately 34 million people worldwide and is responsible for the Acquired Immunodeficiency Syndrome (AIDS), chronic disease that goes beyond the biological context and affects the social relations, mental health, economic aspects and quality of life. ${ }^{1}$

In Brazil, 798,366 cases of AIDS have been registered since the beginning of the epidemic until June 2015. Of these, 519,183 (65.0\%) were male and $278,960(35.0 \%)$ in women, concentrated in key populations: gays and men who have sex with men, transvestites and transsexuals, drug users and sex professionals. $^{2}$

HIV/ AIDS is a chronic generator of stress and living with it represents coping with a variety of situations, such as disruption in affective and social relationships, exclusion and stigma, among others. This contributes to the impairment of physical and mental health, well-being and also quality of life (QoL). ${ }^{3-4}$

Since 1996, the Brazilian public policy on universal access to antiretroviral therapy (ART) has reduced the HIV morbidity and mortality, increasing survival and giving the disease a chronic character. ${ }^{5}$ From 2013, the immediate onset of ART was instituted for all the people living with HIV/ AIDS (PLHA) after the confirmation of the diagnosis, regardless of the CD4 count. ${ }^{6}$ This measure had the consequence of improving the QoL of the diagnosed people and reducing the probability of virus transmission. ${ }^{7}$

For the World Health Organization, the QoL is considered to be: "the perception of the individual about their position in life, in the context of the culture and value systems in which they are inserted and in relation to their objectives, expectations, standards and concerns. It is a broad-spectrum concept that incorporates in a complex way the physical health, the psychological state, the level of independence and the social relations of the people, as well as their interfaces with important characteristics of their environment". $8: 43$

The QoL is related to the daily life of the people, considering the subjectivity expressed in the perception and expectation about life, in addition to issues related to attitudes towards diseases, ${ }^{9}$ based on the understanding of essential human needs, spiritual, material and, above all, health promotion. ${ }^{4}$

In this context, the application of the Theory of Social Representations, defined as "a form of knowledge, socially elaborated and shared, with a practical objective, and which contributes to the construction of a reality common to a social set,"10:22 in nursing, ensures the understanding of the senses attributed by the subjects to their actions, from the contexts in which they are produced. ${ }^{11}$

Thus, it is important to understand how the PLHA social group understands the QoL and its repercussion in the daily life, since its influence can mean the worsening of the health and well-being of these people. ${ }^{12}$ This is due to the fact that the QoL is a research topic that is still expanding, with few published studies, especially in the field of Social Representations (SR) in the context of HIV/AIDS, as pointed out by some authors. ${ }^{13}$

The QoL construct has a significant contribution potential for the practice of health and nursing care for PLHA and, at the same time, for the 
planning of public policies in this area. ${ }^{14}$ Thus, it is important to emphasize that in the clinical and physical follow-up of these people, the assessment of their QoL should be performed, since professionals need to be aware of the factors that affect the QoL of these people. ${ }^{15}$

In this sense, in recent years, interest in the development of research to assess the QoL of individuals with HIV/AIDS, based on human needs, has been increasing, since PLHA are affected by the chronic nature of the disease, extending from the clinical-laboratory results to the sociocultural and bioethical dimensions. ${ }^{16}$

The identification of the PLHA factors that can be modified is fundamental for health decision making, for the implementation of care strategies and for the optimization of the use of resources from the health services, with the aim of improving the well-being of these people. ${ }^{17}$

Currently, PLHA's greatest concern is to increase or improve QoL, not related only to the efficacy of life-prolonging treatments, ${ }^{18}$ but also in relation to personal and social spheres, which promote social isolation and low self-esteem, hampering the interpersonal relationships. In addition, it requires changes in lifestyle, to better match the treatment with daily routines. ${ }^{19}$

Thus, it is essential to understand the QoL of PLHA, since AIDS is a chronic infection, with the possibility of treatment and greater survival, stigmatized, communicable and incurable, which generates several bio psychosocial consequences that impact the QoL. ${ }^{20}$

It should be noted that this study is part of the integrated project entitled: "Quality of life and symbolic constructions of people living with HIV/ AIDS in Rio de Janeiro", being relevant due to the impact of the HIV/AIDS pandemic on PLHA's QoL in different social contexts and influenced by the changes in the characteristics of the disease over the years.

From the what has been exposed, this study aimed to analyze the social representations of the quality of life of people living with HIV/AIDS.

\section{METHOD}

This is a descriptive, exploratory, qualitative approach, based on the Theory of Social Representations, proposed by Serge Moscovici, ${ }^{21}$ using the structural approach. ${ }^{22}$
The study was carried out in three Specialized Care Services for HIV/AIDS (SAE - Serviços de Atendimento Especializado), located in three $\mathrm{Mu}-$ nicipal Health Centers in the city of Rio de Janeiro, one located in the program area 2.2 and two in the program area 2.1. The choice of SAEs was justified because they provide comprehensive care to users living with HIV/AIDS, through actions of care, prevention and treatment with the work of a multiprofessional team, in addition to allowing access to population groups with different socioeconomic profiles.

The study participants were PLHA in therapeutic follow-up in the SAEs of HIV/AIDS that are part of this study. The inclusion criteria of the participants were: to be in the SAE at the time of data collection, waiting for a consultation, information or examinations; to be 18 years old or older; to have mental conditions that allow the participation in the study, and to have positive serology for HIV.

The total number of participants in this study was established by sampling of the non-probabilistic, convenience type, chosen from information provided by the SAE of the number of clients in the follow-up. 180 people living with HIV/AIDS participated in the study, 60 of each service. The total numbers of subjects have responded to the instrument of socioeconomic and clinical data, and also to the form of free evocations.

The participants were invited to take part in the study on a voluntary basis, according to their presence and availability in the SAE, respecting the ethical and legal aspects according to the Resolution 466/12 of the National Health Council, and it was approved by the Research Ethics Committee of the Municipal Health Secretary of Rio de Janeiro with Opinion No. 1,441,788, recorded under the CAAE No. 47411315.7.3001.5279.

The data collection was carried out from April to May 2016, with the self-application of a questionnaire with socioeconomic and clinical variables, followed by the application by the researcher of the form of free speech evocations. The socioeconomic and clinical data instrument contains identification variables of the participants, such as: gender, age, schooling, approximate monthly personal income, and also clinical variables such as the time of ARV use, the presence of symptoms associated with medications, among others.

The technique of data collection of free word evocations was applied with the inducer term "qual- 
ity of life", in which it was requested the verbalization of five words or expressions that came to mind after the enunciation of this term. The evoked words were written in a free evocations form.

The analysis of socioeconomic and clinical data was performed by arranging them in tables and graphs with absolute and relative frequencies, with the help of the Excel software ${ }^{\circledR}$ and SPSS ${ }^{\circledast}$.

The analysis of the contents and the structure of the RS of the QoL from the free evocations was performed by the Technique of the Four-house Table, with the aid of the software called Ensemble de Programmes Permettant L'analyse des Evocations $\left(E{ }^{\circledR}\right)$, version 2005 , which resulted in the construction of a frame with four quadrants from the frequency and order of the terms evoked. ${ }^{23}$ For this, the following steps were respected: all the evocations were typed in the manner and in the order in which they were evoked, in the Microsoft Word format ${ }^{\circledR}$; orthographic correction of the words and terms evoked, reducing them to the core of the sentence to be processed by the software; standardization of the words and terms evoked, guaranteeing the maintenance of the final meaning expressed by them and that, simultaneously, could be identified by the software as synonyms. At the end, a dictionary of standardization of evocations was elaborated, in order to maintain the semantic content expressed by the subjects, reducing their dispersion. Thus, a corpus referring to the term inductor was obtained, which was processed by the $\mathrm{EVOC}^{\circledR}$ software $^{\circledR}$. Then, from the intersection of the frequency and position of the evocations, the four-house table was generated, which expresses the contents and the structure of the SR about the object under analysis. ${ }^{23-24}$

Thus, the upper left quadrant is formed by the elements of the probable central nucleus, which are the elements with lower mean of the Mean Orders of Evocation (MOE) and elements with frequency greater than or equal to the average frequency established by the researcher. ${ }^{24}$

The right upper quadrant (first periphery) is formed by the most important peripheral elements with high frequencies, and may be central to the representation. The lower right quadrant (the second periphery) includes the less frequent and less important elements, since it consists of later evoked elements, but with a predominant role in the relation of SRs to everyday practices..$^{23-24}$

The lower left quadrant includes elements that are not evoked, that is, with low frequency, but considered important for the participants that evoked them, thus constituting a zone of contrast of the representation, which may indicate the existence of a subgroup that maintains representations that are different from the group analyzed or, even, elements that reinforce the cognitions present in the central nucleus or in the periphery. ${ }^{24}$

\section{RESULTS}

The sociodemographic and clinical characterization of the participants shows that there is a predominance of males, with 147 (81.7\%) individuals, and only $33(18.3 \%)$ females. The predominant age group is 30 to 39 years old, corresponding to 51 (28.3\%) participants. Regarding schooling, 80 (44\%) reported having complete high school or incomplete higher education, and 91 (50.6\%) stated that they did not have a boyfriend or a fixed partner, and $107(59.5 \%)$ individuals reported to be living with the family.

Regarding their personal income in "reais", it is concentrated in the range of $R \$ 1,000.00$ to $R$ \$ $3,000.00$, comprising $85(47.2 \%)$ participants. At the same time, $129(71.7 \%)$ individuals report that they are employed or working, which represents more than $50 \%$ of the group.

Regarding the clinical characterization and health practices, $90(50 \%)$ participants state that they are homosexual. Regarding the current stage of the infection, 169 (93.9\%) participants declare that they do not have symptoms. Regarding the use of ART, almost all of them stated that they used medication, which corresponds to 171 (95\%) participants. Regarding the assessment of their own health and QoL, $84(46.7 \%)$ individuals interviewed considered their health good, and 98 (54.4\%) individuals also assessed their QoL as good.

As for the product of the free evocations, the software used in the treatment of the data identified in the corpus 802 words or expressions evoked, being 137 different. In order to process the content, it was necessary to establish previously: the minimum frequency of the words, being defined in 14, with the exclusion of terms that were evoked below this frequency; calculation of the mean evocation frequency, which corresponded to 29 . From these frequencies, the program calculated the mean MOE, which corresponded to 2.83, and was adjusted to 2.8 .

Based on the defined parameters and with the support of the EVOC® software, the Four-house Table was created and presented in Table 1. 
Table 1 - Four-house Table to the term inducer "quality of life" for PLHA. Rio de Janeiro-RJ 2016. (n=180)

\begin{tabular}{|c|c|c|c|c|c|c|}
\hline & $<2.8$ & & & $\geq 2.8$ & & \\
\hline FreqMed & Evoked term & Freq & M.O.E. & Evoked term & Freq & M.O.E. \\
\hline$\geq 29$ & $\begin{array}{l}\text { good-nutrition } \\
\text { health } \\
\text { good } \\
\text { health-care }\end{array}$ & $\begin{array}{l}55 \\
49 \\
36 \\
32\end{array}$ & $\begin{array}{l}2.655 \\
2.531 \\
1.722 \\
2.375\end{array}$ & $\begin{array}{l}\text { physical-activity } \\
\text { leisure }\end{array}$ & $\begin{array}{l}60 \\
39\end{array}$ & $\begin{array}{l}3.050 \\
3.128\end{array}$ \\
\hline$<29$ & $\begin{array}{l}\text { work } \\
\text { living-well } \\
\text { medications } \\
\text { normal-life } \\
\text { treatment }\end{array}$ & $\begin{array}{l}26 \\
25 \\
23 \\
18 \\
17\end{array}$ & $\begin{array}{l}2.385 \\
2.240 \\
2.174 \\
2.500 \\
2.588 \\
\end{array}$ & $\begin{array}{l}\text { joy } \\
\text { family } \\
\text { sleeping-well } \\
\text { prevention } \\
\text { solidarity }\end{array}$ & $\begin{array}{l}22 \\
22 \\
15 \\
14 \\
14\end{array}$ & $\begin{array}{l}3.273 \\
3.091 \\
3.867 \\
3.429 \\
3.429 \\
\end{array}$ \\
\hline
\end{tabular}

The elements that constitute the probable central nucleus of representation defined as the most important were: "good", "good-nutrition, healthcare and health". All express positive meanings, being "good" an evaluative dimension regarding the QoL, "good-nutrition" a physical-corporal dimension, and "health-care" and "health" a dimension of health care. These dimensions organize different terms that express the same notion of QoL.

The most frequent term, that is, the most evoked by the participants, was "good-nutrition", presenting a frequency of 55. Concomitantly, it is the term that presents the largest MOE (2.655), indicating that it was the later evoked element among the others that make up the central nucleus. The presence of this term in the probable central nucleus of the QoLSR reflects the importance given by the participants to an adequate and healthy diet for the promotion of health, and consequently for the maintenance of one's own health. In this sense, feeding is considered as part of the health self-care, being an element valued in the context of the QoL of the participants.

The element most promptly evoked, that is, the first remembered more spontaneously by the participants, was good, presenting, therefore, the lowest MOE, which is 1.722. This term is characterized as attitudinal and expresses a positive assessment of the QoL by the participants, corroborating the result presented in the questionnaire in relation to this aspect.

The term "health" presents frequency 49, standing out as the second most important for the participants. The presence of this element indicates that, for the participants living with HIV/AIDS, health is a fundamental element for the preservation of the QoL, which is assessed as "good" and manifested by the "health" condition and the aspects that surround it, such as well-being and absence of opportunistic symptoms and diseases.
The term "health-care" presents high frequency and the second lower MOE (2.375). The presence of this word in the possible central nucleus seems to demonstrate the awareness of the interviewees about the importance of self-care in the daily life of PLHA, also indicating that health care is essential for obtaining or maintaining a good QoL.

Thus, it is observed that all terms of the possible central nucleus are related and suggest that the psychosocial construction of the PLHA's quality of life is considered positive and is associated with adequate "feeding", which is inserted in the context of self-care and "health care", indicating the concern of those interviewed with their own "health".

Comprising the peripheral system (first and second peripheries), there are the following elements: first periphery - "physical-activity, leisure"; second periphery - "joy, family, sleeping-well, prevention and solidarity". All the elements have positive meanings, reinforcing the positive attitude evidenced in the central nucleus against the QoL. The physical-activity and "sleeping-well" elements express a dimension of physical-bodily care; the elements of leisure and joy, a dimension of self-care; the element "prevention", a dimension of preventive care; and the elements "solidarity and family", a dimension of the care for the other.

By assessing the first periphery, the term "physical-activity" stands out for the high frequency (60) in relation to the others of the peripheral system, presenting the highest frequency of all quadrants. The terms "physical activity and leisure" are the most important of the peripheral system, and the semantic context of leisure includes activities such as travel, going to the beach, theater and cinema, among others. In addition, both reinforce the elements present in the upper left quadrant, since, besides being positive, they are related to health care in the context of health promotion actions. 
In the second periphery, the elements of highlight are "joy and family" due to the higher frequencies and lower MOEs of this quadrant.

The terms "solidarity and prevention" are the elements with the lowest frequencies of the whole picture of the four-house table of the SR in evidence, being less expressive.

The term "solidarity" indicates the concern of the interviewees with the other, expressing a vision of collectivity and empathy with the suffering of the other.

Regarding the term "prevention", it suggests, in addition to the concern not to transmit HIV to the partner, the concern with their self-protection, in order to avoid the reinfection or opportunistic diseases. The term "family" indicates the importance of family social support as a facilitating element in the daily life of PLHA in the face of the difficulties imposed by the disease. The term "sleeping-well" has the highest MOE of the entire four-house table, indicating that it was the least evoked element by the participants, that is, the least important. This element expresses a basic physiological need, that is the rest of the body and mind, being a physical and corporal care that was remembered for its contribution to the promotion of well-being and, consequently, to a good QoL.

The elements present in the contrast zone are terms with low frequency and low MOE, that is, those less mentioned and more promptly evoked by the participants, therefore considered important for the few who evoked them. That is: "work, living-well, medications, normal-life and treatment". Considering the elements present in the other quadrants, the terms "work, medications, treatment and normal-life" express distinct representational contents, not highlighted in the general representational structure.

The elements "work and normal-life" point to the regularity of life, even in the presence of HIV and AIDS, and may point to the naturalization of the virus and the disease. The term "work" was the most expressive of the contrast zone, due to the higher frequency between the elements of this quadrant, evidencing the importance of the work activity and social insertion to obtain a satisfactory QoL.

The terms "medications and treatment", in turn, express the prominence of clinical care for the maintenance of PLHA's QoL. The term "medications" was the most promptly evoked in this quadrant, with an MOE of 2.174, being the second lowest MOE of the entire four-house table. The low
MOE of this element indicates the importance given by the subjects to the drug treatment process. Such spontaneity reflects that the medications are inserted in the daily life of the PLHA, being part of the daily life in such a way that they participate in the conditions for a good QoL, placing itself as a central element for a part of the subjects participating in the study. It is possible to propose the existence of an alternative representation for a subgroup of the general group analyzed.

On the other hand, the term "treatment", despite being included in the dimension of medication care, as well as the term "medications", presented the highest MOE, since it was the later element evoked by the participants, and that also presented the lowest frequency of the lower left quadrant, indicating little importance of the term attributed by the subjects. This seems to suggest that the term "medications" is more present in the daily language of the participants, since it is directed to the use of ART, being essential for the maintenance of the PLHA's health, directly related to their good QoL. On the other hand, the term "treatment" seems to be a secondary element for the participants in the dimension of medication care.

\section{DISCUSSION}

In the central nucleus of SR of the QoL there are representational contents related to positive assessment, to nutrition, to health care and to health. These elements are a necessary condition for a good QoL, and consist in health care, especially healthy nutrition, which contributes to the maintenance of a balanced health status. This is evident in the results of the present study, since the majority of PLHA assesses the QoL and health positively, as good and very good, as pointed out in the characterization of the group studied.

The central nucleus is formed by normative and functional elements, ${ }^{25}$ thus, it is considered that the contents "good-nutrition" and "health-care" are functional, since they have an operative purpose, related to social practices. The good and "health" elements are normative, since they are related to the system of values of the studied social group, establishing the positions and the judgment regarding an object.

Regarding the attitudinal element present in the central nucleus, QoL is associated with a positive assessment, even in the presence of the virus and the disease. This assessment permeates all the representational elements, allowing affirming that 
this is a positive representation. The positive assessment of QoL by the PLHA is also found in studies of this theme. ${ }^{18,26}$ A similar result is also found in another study, ${ }^{27}$ in which the term "good-nutrition" integrates the possible central nucleus, having the highest frequency in the upper left quadrant.

Regarding feeding, the adoption of a balanced and healthy diet is considered as self-care, which contributes to the promotion of health and to the prevention of diseases, favoring the improvement of the QoL. ${ }^{28}$

In this context, a healthy nutrition provides an increase in the number of T CD4+ lymphocytes and, consequently, the strengthening of the immune system. In addition, the association of the drug treatment with the nutritional treatment decreases the mortality rate, increasing the survival of PLHA. Thus, adequate nutrition hinders the appearance of opportunistic diseases and contributes to a satisfactory QoL. ${ }^{29}$ These factors, in whole or in part, should integrate the knowledge of the group about the value of adequate nutrition, both in terms of quality and quantity, and therefore recognize the importance of food in health promotion, adding them to their representations.

The health care in a sickness situation reflects, simultaneously, the care with the disease or the strategies necessary to avoid the aggravation of the disease, and also the self-care for health maintenance. Thus, health care is understood as a set of knowledge and attitudes that lead to changes in the lifestyle, implying improvement in health, demonstrating its strong association with the QoL.

Regarding this aspect, a study on PVHA's QoL ${ }^{30}$ observed that health care is related to the nutrition care, since a healthy diet directly affects the treatment, being essential for individuals to have or improve their QoL. In addition, it was emphasized that the clients are concerned with healthier lifestyles, through changes in behavior, attitudes and lifestyle associated with the proper use of ARVs, in order to live better with the virus.

It is in the act of caring that healing can reside, as is the case of AIDS. In the absence of any illness and in the daily life of human beings, the human care is also indispensable, both as a way of living and of relating. ${ }^{31}$

It is observed that, in the peripheral system of the SR analyzed, health promotion practices are highlighted as defining of the QoL. These practices are, in a first group, the physical activity, leisure, sleeping well, joy, as strategies to search for a healthy body and mind. In a second group, the family and solidarity stand out as strategies of social insertion and predictors of QoL improvement, providing psychological well-being. ${ }^{32}$

These elements of the peripheral system are directed towards caring for oneself, linked to the satisfaction of individual needs related to rest, sleep, physical and leisure activities, as well as to affective relationships coming from the social interaction with friends, family, or coworkers. ${ }^{33}$

Physical activity, leisure, sleeping, and joy in the context of AIDS are perceived as practices that promote benefits for the general clinical status, functional capacity and health-related physical fitness, such as improved strength and muscular resistance, as well as to several psychological aspects, such as the reduction of depression and anxiety. In addition, they serve as stimuli to acquire healthy habits of life. ${ }^{34}$ This assertion is consistent with the results obtained in a study on the level of physical activity in PLHA, ${ }^{35}$ which showed that the active individuals, that is, those who performed physical activities, presented higher scores in the domains of QoL of PLHA than those who had a sedentary life.

In turn, family, solidarity and work express the social and moral supports for a good QoL. The work represents a foundation in the individuals' lives, being a reason for their existence, therefore, through this, the individuals feel productive before the society. In this sense, in two studies, ${ }^{27,32}$ the element work appeared in the probable central nucleus of QoL SR.

In the contrast zone, it is possible to find the dissonant representational contents of the analyzed representation, that is, those that express contrast with the dominant central nucleus in the analyzed representation, demonstrating the existence of a subgroup with distinct representation of the general group. ${ }^{25}$ In this analysis, it is observed the existence of a set of dissonant elements of the contents of the general representation, as pointed out.

The condition of living well and having a normal life express the naturalization of PLHA's daily life, even in the presence of HIV and possibly AIDS, both of which are necessary conditions for the promotion of QoL. This result is similar to another study, ${ }^{27}$ in which the expression living well points to the value of life itself, after the discovery of the positive diagnosis for HIV, since before they did not have the concern regarding the health care for the maintenance of life. As a result, they began to value healthy habits, such as adequate nutrition and physical activity. These practices should enable a better life than before diagnosis, allowing 
the experiencing life with quality, valuing health and well-being.

Regarding prevention, the use of condoms is the main practice to avoid the transmission of the virus, as well as to avoid virus exchange between PLHA. In addition, it is considered a healthy living habit that reduces the risk of acquiring HIV and also other sexually transmitted infections. ${ }^{36}$

The access to treatment and the clinical control have brought benefits and life expectancy to clients in the context of a pathology of significant social impact. ${ }^{37}$ According to the participants' assessment, the treatment includes medical consultations and follow-up, examinations, regular and ongoing use of medications, safe sex prevention with the condom use, and prevention of opportunistic diseases. ${ }^{12}$

The medications express a health care that is necessary for the survival and also for a better quality of life of PLHA. However, the use of ARVs is contradictory, since it concomitantly increases life expectancy and generates several adverse effects and also requires adaptations in the daily life for its administration. ${ }^{30}$

In this context, health services take on the role of potentiators of QoL, since they identify the factors that affect PLHA's QoL, collaborating for a more humanized care to these people, through care actions that go beyond the drug treatment, consultations and exams, including, also, psychological support. Thus, the guidance received from health professionals is of great relevance to these people and aids in behavior change, in the search of a healthy life. ${ }^{30}$

The contents and the internal organization of the SR in evidence provide a coherent panorama between the possible central and peripheral elements that allow us to understand how the group thinks and positions itself about the QoL. However, the technique of analysis of the content evoked with its respective organization does not enable us to confirm if those elements of the upper left quadrant are in fact the central elements, that is, those that have greater significance in the context of the social thought of the group. The confirmation of the central elements of a representation sometimes shows that terms of the first periphery are central and those with a first indication of centrality are not. Although it does not always significantly interferes with the understanding of the representation of a social group, it is still a limitation of the study.

From what has been showed, it is suggested as a possibility of future studies the performance of centrality tests to confirm the elements effectively central in the representation, complementing in a more consistent way the results analysis.

\section{CONCLUSION}

The possible central nucleus evidences a positive position on QoL, but also expresses the group's judgment about its own QoL, assessing it as good. These elements, as well as peripheral ones, are related to the dimensions of the physical-body care, self-care and care for the other, showing the concern not only with one's own health, but also with the other as part of a satisfactory QoL.

In relation to the contrast zone, contents related to the representational dimensions of self-care, drug care and physical-body care were observed, encompassing the elements that constitute health care, thus reinforcing the possible central nucleus of QoL SR.

The QoL SR for PLHA were built with the central elements of nutrition quality and health, configuring a dimension of physical and corporal care; health care, expressing a dimension of health care; and good, constituting a positive assessment dimension regarding the QoL.

From this perspective, the SR of QoL of PLHA consists in the accomplishment of health care directed mainly to the promotion of health, especially the maintenance of a healthy diet and the practice of physical activities. It is believed that the fact that the majority of the participants state the absence of symptoms in relation to the current stage of the disease influences the constructed representation of the QoL, since the absence of symptoms can represent the absence of the disease, in addition to allowing the accomplishment of the daily life activities, providing well-being.

This context encourages us to think about some issues. The first one is that the projective technique does not allow the group to formulate a structured thought, because the content is placed objectively and punctually, but, nevertheless, it can be inferred that there is a concept of QoL implicit in it. In a first attempt to express this concept or psychosocial thinking about the object, it can be said that, for the group studied, the QoL represents or means being health from diet, treatment and several health promotion practices.

Thus, the QoL SR is structured by meanings that express health and health promotion practices aimed at physical-corporal care, medical care and psychosocial care. 
The other aspect that deserves consideration is the fact that the representation does not constitute an autonomous representation, that is, with its own contents, because its construction is strongly anchored to elements related to health. This association can be explained by the fact that health is a priceless asset and of value character for the group studied, since it is a living condition that the members lost or that is in constant threat and that, therefore, they need to recover and to maintain under control to continue living.

Finally, it is considered that, based on the analysis of the QoL SR among PLHA, it is possible to reflect on what can be improved in the care provided by nurses, aiming to improve the care provided to clients who have HIV/AIDS, making possible the dialogue between clients and professionals, from the ways of thinking of the service users.

\section{REFERENCES}

1. Cardona-Arias JA, Higuita-Gutierrez LF. Impacto del VIH/SIDA sobre la calidad de vida: metaanálisis 2002-2012. Rev Esp Salud Publica [Internet]. 2014 JanFeb [cited 2016 May 12]; 88(1):87-101. Available from: http:/ / www.scielosp.org/scielo.php?script=sci_ arttext\&pid=S1135-57272014000100006

2. Ministério da Saúde (BR). Secretaria de Vigilância em Saúde. Departamento de DST, Aids e Hepatites Virais. Boletim Epidemiológico - Aids e DST. Brasília (DF): MS; 2015.

3. Vieira FMA. Qualidade de vida de pessoas com Aids em uma região portuária do sul do Brasil [dissertação]. Florianópolis (SC): Universidade Federal de Santa Catarina, Programa de PósGraduação em Enfermagem; 2008.

4. Gaspar J, Reis RK, Pereira FMV, Neves LAS, Castrighini CC, Gir E. Quality of life in women with HIV/AIDS in a municipality in the State of São Paulo. Rev Esc Enferm USP[Internet]. 2011 [cited 2016 Aug 11]; 45(1):230-6. Available from: http://www. scielo.br/scielo.php?script=sci_arttext $\&$ pid $=$ S0080 62342011000100032\&lng=en\&nrm=iso\&tlng=en

5. Cunha GH, Fiuza MLT, Gir E, Aquino PS, Pinheiro AKB, Galvão MTG. Quality of life of men with AIDS and the model of social determinants of health. Rev Latino-am Enfermagem [Internet]. 2015 MarApr [cited 2016 Aug 30]; 23(2):183-91. Available from: http://www.scielo.br/scielo.php?script=sci_ arttext\&pid=S0104-11692015000200002\&lng=en\&nr $\mathrm{m}=$ iso\&tlng=en\&ORIGINALLANG=en

6. Ministério da Saúde (BR). Secretaria de Vigilância em Saúde. Departamento de DST, Aids e Hepatites Virais. Protocolo clínico e diretrizes terapêuticas para manejo da infecção pelo HIV em adultos. Brasília (DF): MS; 2013.
7. Ministério da Saúde (BR). Secretaria de Vigilância em Saúde. Departamento de DST, Aids e Hepatites Virais. Manual Técnico para o diagnóstico da infecção pelo HIV. Brasília (DF): MS; 2014.

8. The WHOQOL Group. The development of the World Health Organization quality of life assessment instrument (the WHOQOL). In: Orley J, Kuyken W, editors. Quality of life assessment: international perspectives. Heidelberg (DE): Springer Verlag; 1994.

9. Almeida MAB, Gutierrez GL, Marques R. Qualidade de vida: definição, conceitos e interfaces com outras áreas de pesquisa. São Paulo (SP): Universidade de São Paulo; 2012.

10. Jodelet D. Representações sociais: um domínio em expansão. In: Jodelet D, organizadores. As representações sociais. Rio de Janeiro (RJ): EdUERJ; 2001.

11. Ferreira MA. Theory of Social Representations and contributions to the research of health care and nursing. Esc Anna Nery [Internet]. 2016 [cited 2016 Aug 17]; 20(2):214-9. Available from: http://www. scielo.br/scielo.php?script=sci_issuetoc\&pid $=1414$ 814520160002\&lng=en\&nrm=iso

12. Domingues JP. Representações sociais da qualidade de vida e do cuidado de saúde de pessoas que vivem com HIV/aids no município do Rio de Janeiro [dissertação]. Rio de Janeiro (RJ): Universidade do Estado do Rio de Janeiro, Programa de Pós-Graduação em Enfermagem; 2017.

13. Hipolito RL, Oliveira DC, Gomes AMT, Costa TL. A teoria das representações sociais e a qualidade de vida/HIV/aids: revisão integrativa de literatura. Rev Pesq: Cuid Fundam Online [Internet]. 2016 JanMar [cited 2016 Aug 13]; 8(1):3609-3623. Available from: http://www.seer.unirio.br/index.php/ cuidad ofundamental/article/viewFile/3592/ pdf_1760

14. Costa TL, Oliveira DC, Gomes AMT, Formozo, GA. Quality of life and people living with AIDS: relationship with sociodemographic and health aspects. Rev Latino-am Enfermagem [Internet]. 2014 Jul-Agu [cited 2016 May 15]; 22(4):582-90. http:/ / www. scielo.br/scielo.php?script=sci_arttext\&pid=S010411692014000400582\&lng=en\&nrm=iso\&tlng=e

15. Passos SMK, Souza LDM. An evaluation of quality of life and its determinants among people living with HIV / AIDS from Southern Brazil. Cad Saúde Pública [Internet]. 2015 Apr [cited 2016 Oct 10]; 31(4):800-14. Available from: http:/ / www.scielosp.org/pdf/csp/ v31n4/0102-311X-csp-31-04-00800.pdf

16. Oliveira, FBM, Moura MEB, Araújo TME, Andrade EMLR. Qualidade de vida e fatores associados em pessoas vivendo com HIV/AIDS. Acta Paul Enferm [Internet]. 2015 [cited 2016 Oct 11]; 28(6):510-6. Available from: http://www.scielo.br/pdf/ape/ v28n6/1982-0194-ape-28-06-0510.pdf

17. Okuno MFP, Gosuen GC, Campanharo CRV, Fram DS, Batista REA, Belasco AGS. Quality of life, 
socioeconomic profile, knowledge and attitude toward sexuality from the perspectives of individuals living with Human Immunodeficiency Virus. Rev Latinoam Enfermagem [Internet]. 2015 [cited 2015 Oct 12]; 23(2):192-9. Available from: http:/ / www.scielo.br/ pdf/rlae/2015nahead/pt_0104-1169-rlae-3424-2542. pdf

18. Oliveira Filho JS, Silva PE, Freitas FFQ, Soares JP, Costa MAG, Silva ACO. Qualidade de vida de pessoas vivendo com HIV/ AIDS. Rev Baiana Enferm [Internet]. 2014 Jan-Feb [cited 2016 May 24]; 28(1):618. Available from: https://portalseer.ufba.br/index. php/enfermagem/article/download/9088/8707

19. Reis RK, Santos CB, Dantas RAS, Gir E. Qualidade de vida, aspectos sociodemográficos e de sexualidade de pessoas vivendo com HIV/aids. Texto Contexto Enferm [Internet]. 2011 [cited 2016 Jun 1]; 20(3):56575. Available from: http://www.scielo.br/pdf/tce/ v20n3/19.pdf

20. Soares GB, Garbin CAS, Rovida TAS, Garbin AJÍ. Qualidade de vida de pessoas que vivem com HIV/AIDS assistidas no serviço especializado em Vitória (ES), Brasil. Ciênc. Saúde Coletiva [Internet]. 2015 [cited 2016 Sep 2]; 20(4):107584. Available from:http://www.scielo.br/scielo. php? pid=S141381232015000401075\&script $=$ sci arttext\&tlng $=\mathrm{pt}$

21. Moscovici S. Representações sociais: investigações em psicologia social. Petrópolis (RJ): Vozes; 2013.

22. Abric JC. A abordagem estrutural das representações sociais. In: Moreira ASP, Oliveira DC, organizadores. Estudos interdisciplinares de representação social. $2^{\mathrm{a}}$ ed. Goiânia (GO): AB; 2000.

23. Sá CP. Núcleo Central das Representações Sociais. $2^{a}$ ed. Petrópolis (RJ): Vozes; 2002.

24. Oliveira DC, Marques SC, Gomes AMT, Teixeira MCTV. Análise das evocações livres: uma técnica de análise estrutural das representações sociais. In: Moreira ASP, Camargo BV, Jesuíno JC, Nóbrega SM, organizadores. Perspectivas teórico-metodológicas em representações sociais. João Pessoa (PB): Editora Universitária da UFPB; 2005.

25. Abric JC. Abordagem estrutural das representações sociais: desenvolvimentos recentes. In: Campos PHF, Loureiro MCS, organizadores. Representações sociais e práticas educativas. Goiânia (GO): UCG; 2003.

26. Medeiros B, Saldanha AAW, Silva J. Determinantes biopsicossociais que predizem qualidade de vida em pessoas que vivem com HIV/AIDS. Estud Psicol [Internet]. 2013 Oct-Dec [cited 2016 Oct 20]; 18(4):54350. Available from: http://www.scielo.br/pdf/epsic/ v18n4/a 01v18n4.pdf

27. Costa TL, Formozo GA, Oliveira DC. Qualidade de vida e AIDS sob a ótica de pessoas vivendo com o agravo: contribuição preliminar da abordagem estrutural das representações sociais. Cad Saúde Pública [Internet]. 2015 Feb [cited 2016 Jun 23];
31(2):365-376. Available from: http://www.scielo. br/pdf/csp/v31n2/0102-311X-csp-31-02-00365.pdf

28. Ferreira ES, Souza M.B, Souza NVDO, Tavares KFA, Pires AS. A relevância do cuidado de si para profissionais de enfermagem. Ciênc Cuid Saúde [Internet]. 2015 Jan-Mar [cited 2016 Nov 14]; 14(1):978-85. Available from: http:/ / www.periodicos. uem.br/ojs/index.php/CiencCuidSaude/article/ viewFile/23360/14206

29. Paula EP, Neres S, Santini E, Reis Filho AD. Considerações nutricionais para adultos com HIV/ aids. REMENFE [Internet]. 2010 Nov-Dez [cited 2017 Jun 27]; 1(2):148-65. Available from: http:/ / www. nutricaoemfoco.com.br/NetManager/documentos/ consideracoes_nutricionais.pdf

30. Meirelles BHS, Silva DMGV, Vieira FMA, Souza SS, CoelhoIZ, Batista R. Percepções da qualidade de vida de pessoas com HIV / AIDS. Rev Rene [Internet]. 2010 Jul-Sep [cited 2016 Nov 25]; 11(3):68-76. Available from: http://www.revistarene.ufc.br/vol11n3_html_ site/a07v11n3.html

31. Waldow VR. Cogitando sobre o cuidado humano. Cogitare Enferm [Internet]. 1998 Jul-Sep [cited 2017 Jun 27];3(2):7-10. Available from: http:/ / revistas.ufpr. br/cogitare/article/view/44316/26805

32. Castanha AR, Coutinho MPL, Saldanha AAW, Ribeiro CG. Avaliação da qualidade de vida em soropositivos para o HIV. Estud Psicol [Internet]. 2007 Jan-Mar [cited 2016 Mai 12]; 24(1):23-31. Available from: http:/ / www.scielo.br/pdf/estpsi/v24n1/v24n1a03.pdf

33. Tomaschewski-Barlem JG, Piexak DR, Barlem ELD, Lunardi VL, Ramos AM. Produção científica da enfermagem acerca do cuidado de si: uma revisão integrativa. Rev Pesq: Cuid Fundam Online [Internet]. 2016 Jul-Sep [cited 2016 Dec 16]; 8(3):4629-35. Available from: http://www.seer.unirio.br/index. php/ cuidadofundamental/article/view/3560/pdf_1

34. Ministério da Saúde (BR). Secretaria de Vigilância em Saúde. Departamento de DST, Aids e Hepatites Virais. Recomendações para a prática de atividades físicas para pessoas vivendo com HIV e aids [Internet]. 2012 [cited 2016 Dec 17]; Available from: http:/ / www.aids.gov.br/sites/default/files/anexos / publicacao/2012/51379/manual_atividade_fisica_ pdf_30859.pdf

35. Gouvêa-e-Silva LF, Said RC, Kietzer KS, Freitas JJS, Xavier MB. Nível de atividade física e síndrome lipodistrófica em pacientes com HIV/aids. Rev Bras Med Esporte [Internet]. 2016 Mar-Abr [cited 2016 Dec 15]; 22(2):147-52. Available from: http:/ / www.scielo. br/pdf/rbme/v22n2/1517-8692-rbme-22-02-00147. pdf

36. Silva RAR, Silva RTS, Nascimento EGC, Gonçalves $\mathrm{OP}$, Reis MM, Silva BCO. Perfil clínico-epidemiológico de adultos HIV-positivo atendidos em um hospital de Natal/RN. Rev Pesq: Cuid Fundam Online [Internet]. 2016 Jul-Set [cited 2017 Jun 26]; 8(3):4689-96. Available 
from: http://www.seer.unirio.br/index.php/ cuidadofundamental/article/view/4294/pdf_1

37. Rodrigues Junior AL, Castilho EA. A epidemia da aids no Brasil, 1991-2000: descrição-temporal. Rev
Soc Bras Med Trop [Internet]. 2004 Aug [cited 2016 Jun 15]; 37(4):312-7. Available from: http://www. aids.gov.br/publicacao/2004/epidemia-de-aids-nobrasil-1991-2000-descricao-espaco-temporal the Creative Commons (CC BY). 